\title{
A Study on Career Planning Guidance for College Students from the Perspective of Enterprises
}

\author{
Ting Zhang \\ Enrollment and Vocational Guidance Department, Neijiang Normal University, Neijiang, Sichuan, \\ China, 641112 \\ 13990537782@163.com
}

Keywords: Career planning guidance; Enterprises; College students

\begin{abstract}
Through the investigations and visits of colleges and universities, students and some representative enterprises, this study analyzes the current situation of the supply and demand condition and career planning guidance of college students. And on the basis of the characteristics of Chinese higher education, career planning theory and individuals' thinking, from the perspective of enterprises, this study also proposes ways and measures to improve college students' career planning guidance level, including the government to strengthen the macro policy guidance, enterprises to play a positive role, and schools to improve the way of reform guidance.
\end{abstract}

\section{Introduction}

Career planning refers to the trade-off analysis towards individual personality based on the analysis of subjective and objective conditions, fully considering the characteristics of organizations and the society, to clear their career goals, so as to make a reasonable and effective career arrangement. In recent years, with the development of domestic economy, enterprise's demand for college students is increasing rapidly, and "difficult to recruit people" phenomenon is very outstanding. With the expansion of college enrollment, college graduates' employment problems have caused the wide attention of the society. The emergence of these problems is greatly related to the lack of scientific and reasonable career planning guidance for college students.

For college students, carrying out career planning guidance can help them to have a correct understanding of their own, developing correct professional ideal, then to promote the high quality employment. Career planning guidance can also instill the excellent modern corporate cultures, corporate philosophy and necessary professional quality into the study of college students, to realize the seamless joint of industries, then to integrate campus culture and enterprise culture, laying new avenues of cooperation between colleges and enterprises, so as to improve the level of running a college. It can cultivate high-quality human resources for enterprises, further reducing the differences between talents needs of enterprises and current situation of talents cultivation in colleges and universities, to maximize the economic benefits of enterprises. In addition, it helps to alleviate the employment pressure, optimizing the structure of social human resources, promoting social stability. The rational development of college student occupation career planning will eventually help to achieve multi-win among enterprises, schools, students and the society.

\section{Analysis of the Supply and Demand of College Students}

Enterprises' Demand for College Students. Institutions of higher learning have become China's important talent output place, which conforms to the requirements of social and economic development. Enterprises are the main demander of talents, and college students with the operational skills of the base line constitute the indispensable basic position of enterprises. At the same time, enterprises are also the main platform for college students to achieve personal ideals, value and life goals. This paper analyzes an enterprise's demand for college students from the aspects of demand quantity, majors and competencies. This study has investigated Xiangtan enterprises' demand for college students, and finds that the enterprises' demand for four professions is now relatively large. Specific statistical results are shown in Table 2-1. 
Table 2-1 Statistical situation of higher vocational education

\begin{tabular}{|c|c|c|c|c|c|c|c|}
\hline Profession & $\begin{array}{c}\text { Manufact } \\
\text { ure }\end{array}$ & Finance & $\begin{array}{c}\text { Electronic } \\
\text { informatio } \\
\mathrm{n}\end{array}$ & $\begin{array}{c}\text { Agricultur } \\
\text { e \& } \\
\text { Farming }\end{array}$ & $\begin{array}{c}\text { No } \\
\text { demand }\end{array}$ & Others & Total \\
\hline $\begin{array}{c}\text { Selection } \\
\text { ratio }\end{array}$ & $32 \%$ & $30 \%$ & $24 \%$ & $7 \%$ & $4 \%$ & $3 \%$ & $100 \%$ \\
\hline
\end{tabular}

In the investigation and study, this article summed up the essential quality of students, and the questionnaire requires enterprises to mark the most important five professional qualities. Through the weighted average, the results are shown in Table 2-2.

Table 2-2 Statistical situation of higher vocational quality

\begin{tabular}{|c|c|c|c|c|c|c|c|c|}
\hline $\begin{array}{c}\text { Professi } \\
\text { onal } \\
\text { quality }\end{array}$ & $\begin{array}{c}\text { Professi } \\
\text { onal } \\
\text { morality }\end{array}$ & $\begin{array}{c}\text { Team } \\
\text { spirits }\end{array}$ & $\begin{array}{c}\text { Adaptab } \\
\text { ility }\end{array}$ & $\begin{array}{c}\text { Basic } \\
\text { skills }\end{array}$ & $\begin{array}{c}\text { Commu } \\
\text { nication } \\
\text { ability }\end{array}$ & $\begin{array}{c}\text { Innovati } \\
\text { on } \\
\text { ability }\end{array}$ & $\begin{array}{c}\text { Cultural } \\
\text { quality }\end{array}$ & $\begin{array}{c}\text { Professi } \\
\text { onal } \\
\text { knowled } \\
\text { ge }\end{array}$ \\
\hline $\begin{array}{c}\text { Weighte } \\
\text { d } \\
\text { average }\end{array}$ & 5 & 4.9 & 4.8 & 4 & 3.5 & 3 & 2 & 1.5 \\
\hline
\end{tabular}

The Supply of College Students. Based on the investigation of the employment data of the five colleges and universities in Xiangtan City, it can be seen that the total number of students from manufacture, finance and electronic information majors is 44590. In the last three years, there were approximately 14800 college graduates every year. Manufacture, finance and electronic information majors are the largest three major; and for the enterprise that has certain demand of agricultural specialty, these colleges have not set up related professions, so enterprises can only recruit qualified personnel in universities and colleges from other areas.

Students' Self-cognition. Professional choice is not only the start of college students' career planning, but also the starting point of career path, and it sets the basic scope of future career development. Reasonable selection of profession helps college students to give full play to their potential and talent, stimulating their working enthusiasm, to help college graduates gain a firm foothold on the workplace and maintain good career development state. On the other hand, the non-rational professional choice will affect college students' learning enthusiasm, restricting the development of their own ability, which can lead to fuzzy career goals. Following the trend of the professional choice blindly will result in the waste of social education resources, causing the confusion of employment market. This paper investigated the professional choices of college students, and the statistics are shown in Table 2-3.

Table 2-3 Statistical situation of selection method

\begin{tabular}{|c|c|c|c|c|c|c|c|c|c|c|c|c|c|c|c|c|}
\hline \multicolumn{4}{|c|}{ Selection mode of majors } & \multicolumn{4}{|c|}{ Likeability } & \multicolumn{4}{|c|}{ Comprehension degree } & \multicolumn{4}{|c|}{ Major re-selection } & Tota \\
\hline \multirow[t]{2}{*}{$\begin{array}{l}\text { Select } \\
\text { ion } \\
\text { mode }\end{array}$} & $\begin{array}{l}\text { The } \\
\text { ir } \\
\text { ow } \\
\text { n } \\
\text { idea }\end{array}$ & $\begin{array}{l}\text { Paren } \\
\text { ts' } \\
\text { idea }\end{array}$ & $\begin{array}{l}\text { Teacher } \\
\text { s'reco } \\
\text { mmond } \\
\text { ation }\end{array}$ & $\begin{array}{l}\mathrm{Li} \\
\mathrm{ke} \\
\mathrm{abi}\end{array}$ & $\begin{array}{l}\text { Very } \\
\text { much }\end{array}$ & $\begin{array}{l}\text { Gene } \\
\text { rally } \\
\text { like }\end{array}$ & $\begin{array}{l}\text { Don't } \\
\text { like }\end{array}$ & $\begin{array}{l}\text { Com } \\
\text { preh } \\
\text { ensi } \\
\text { on }\end{array}$ & $\begin{array}{l}\text { Unde } \\
\text { rstan } \\
\text { d } \\
\text { very } \\
\text { much }\end{array}$ & $\begin{array}{l}\text { Gene } \\
\text { rally } \\
\text { under } \\
\text { stand }\end{array}$ & $\begin{array}{l}\text { Don } \\
\text { 't } \\
\text { und } \\
\text { erst } \\
\text { and }\end{array}$ & \multirow{2}{*}{$\begin{array}{l}\text { Resele } \\
\text { ction } \\
\text { idea }\end{array}$} & Will & $\begin{array}{l}\text { Will } \\
\text { not }\end{array}$ & $\begin{array}{l}\text { Uncert } \\
\text { ain }\end{array}$ & \\
\hline & 354 & 244 & 82 & $\mathrm{y}$ & 90 & 370 & 220 & ee & 78 & 558 & 44 & & 297 & 143 & 240 & 680 \\
\hline ratio & $\begin{array}{l}52 \\
\%\end{array}$ & $36 \%$ & $12 \%$ & $\begin{array}{c}\mathrm{ra} \\
\mathrm{ti} \\
\mathrm{o}\end{array}$ & $13 \%$ & $54 \%$ & $33 \%$ & $\begin{array}{c}\text { rati } \\
\text { o }\end{array}$ & $11 \%$ & $82 \%$ & $7 \%$ & ratio & $48 \%$ & $20 \%$ & $32 \%$ & 1 \\
\hline
\end{tabular}


Career goal is the goal set by people in the career according to the social requirements and personal conditions, which is the specific objective one wants to achieve in the selected occupation in the future, including short-term goals, medium-term and long-term goals. It can also be considered as the professional realm one desires to achieve. It is an approach for people to achieve personal goals, and is controlled by the social ideal. This study carried out questionnaire survey to understand students' establishment of professional goals, self-cognition of their own characteristics and strengths and also their own development situation. The statistical results are shown in Table $2-4$.

Table 2-4 Statistical situation of career goals

\begin{tabular}{|c|c|c|c|c|c|c|c|c|c|c|}
\hline \multicolumn{2}{|c|}{ Whether there is a career goal } & \multicolumn{3}{|c|}{ The comprehension degree to future } & \multicolumn{3}{|c|}{ Self-cognition degree } \\
\hline & Yes & $\begin{array}{c}\text { Unc } \\
\text { ertai } \\
\mathrm{n}\end{array}$ & No & $\begin{array}{c}\text { Under-st } \\
\text { and }\end{array}$ & $\begin{array}{c}\text { Don't know } \\
\text { much }\end{array}$ & $\begin{array}{c}\text { Don't } \\
\text { understand }\end{array}$ & $\begin{array}{c}\text { Under } \\
\text {-stand }\end{array}$ & $\begin{array}{c}\text { Don't } \\
\text { know } \\
\text { much }\end{array}$ & $\begin{array}{c}\text { Do not } \\
\text { under-stand }\end{array}$ & Total \\
\hline $\begin{array}{c}\text { Selection } \\
\text { number }\end{array}$ & 553 & 109 & 18 & 353 & 293 & 34 & 540 & 92 & 48 & 680 \\
\hline Ratio & $\begin{array}{c}77 \\
\%\end{array}$ & $\begin{array}{c}16 \\
\%\end{array}$ & $\%$ & $51 \%$ & $44 \%$ & $5 \%$ & $76 \%$ & $16 \%$ & $8 \%$ & 100 \\
$\%$
\end{tabular}

Supply and Demand Analysis. This study through the investigation of the number of college students, profession, professional quality and students' self-cognitive status, comprehensively analyzes the needs of enterprises, school supply and students themselves, getting the basic situation of supply and demand of college students currently.

(1) Some professions' supply and demand are not consistent;

(2) Students' self-recognition is low;

(3) The comprehensive quality of students has defects.

\section{The Current Situation of College Students' Career Planning Guidance}

Analysis of the Current Situation. At present, national universities and colleges pay more attention to the guidance of career planning for the students, and the higher vocational colleges have begun to incorporate students' career plan into schools' moral education work, and have preliminary deployment and ideas about the guidance work with a wide range of theoretical research and practical exploration, obtaining some certain instruction results. However, the short history of the career planning guidance, long history of China's institutions of higher education and the poor comprehensive quality of some college students have caused some outstanding problems when colleges and universities are carrying out career planning guidance for students. Following are the specific conditions:

(1) Poor professional career planning awareness;

(2) Imperfect management mechanism;

(3) Insufficient teachers' team for professional guidance;

Analysis of the Causes of Existing Problems. From the Aspect of the Relationship between School and Enterprise. Domestic enterprises in the period of economic transition changed the business model. Enterprises focus on their own business, resulting in the situation that many colleges and universities separate from the original industry enterprises, so the cooperation relationship between school and enterprise gradually evolved from the original "two-way interaction" into a one-way flow relationship that schools provide graduates to enterprise. Colleges and universities do not go deep into enterprises, lacking the understanding of enterprises. Meanwhile, the participation degree of enterprises in higher education is low, which cannot well solve the problem of the absence of responsibilities in higher education, so that the training mode 
combining schools and enterprises cannot be fully implemented.

Analysis from the Social Relationship. Since the reform and opening up, with the establishment of market economic system, China entered the transition period of social value system establishment. We stressed the "people-oriented" idea, but bound by traditional ideas and foreign values, social values; there is a diversified development trend of social values. Under the influence of this social concept, some families will instill the concept that high salary and high position are the same as getting head in life, resulting in the situation that some college students are visionaries in the choice of employment, eager for quick success, and do not want to engage in grass-roots, paying too much attention to high salary and leisure, which can be seen from the civil servant fever in recent years. At the same time, the idea of "get a job first, select later" exists in a lot of employment guidance institutions, which can mislead students when they are choosing a occupation, so the career planning guidance fails to be implemented fully.

\section{Ways and Countermeasures to Improve the Guidance Level of College Students' Career Planning}

Government to Strengthen Macro Policy Guidance, Pay Attention to Vocational College Students' Career Planning Guidance. To guarantee the smooth implementation of college students' career planning guidance, the relevant government departments have the responsibility to formulate and executive macro policy, complete the propaganda work, encourage enterprise and all sectors of society to concern about the development of higher talents, and pay more attention to the guidance work of the college students' career planning from the following aspects.

(1) To establish a sound incentive mechanism;

(2) To develop a sound guidance policy;

(3) To strengthen the management of the employment market;

Enterprises to Play a Positive Role. As the main subject of human resources, enterprises should play an active role in the process of college students' career planning guidance, to strengthen the relationship with colleges, taking the initiative to undertake the social responsibility of training higher vocational students to transport excellent corporate culture to colleges and universities and realize and integration with campus culture, so as to form the cultural resultant forces to cultivate vocational college students. With the cooperation between school and enterprise, both parties can work together to build a career planning guidance platform, closely cooperating with the career planning guidance work of colleges and universities on students.

\section{Conclusion}

Under the background of the modern era, career planning has received the widespread concern from the society. What's more, the employment situation of college graduates directly affects the production and operation of enterprises, influencing students' and their families' interests, the university running level and also social stability. Therefore, study on college students' career planning guidance has extremely important practical significance.

\section{References}

[1] Lee V E, Ekstrom R B. Student access to guidance counseling in high school [J]. American Educational Research Journal, 1987, 24(2): 287-310.

[2] Super D E. Assessment in career guidance: Toward truly developmental counseling [J]. Personnel \& Guidance Journal, 1983, 61(9).

[3] Hackett G, Esposito D, O'Halloran M S. The relationship of role model influences to the career salience and educational and career plans of college women [J]. Journal of Vocational Behavior, 1989, 35(2): 164-180. 
[4] Fisher T A, Padmawidjaja I. Parental influences on career development perceived by African American and Mexican American college students [J]. Journal of Multicultural Counseling and Development, 1999, 27(3): 136.

[5] Gilmour Jr J E. How High School Students Select a College [J]. 1981. 